\title{
Analyzing Stress Coping Strategies and Approaches of School Teachers
}

\author{
Syed Nsir Hussain* \\ Asia Zulfqar ${ }^{* *}$ \\ Fakhra Aziz $^{* * *}$
}

\begin{abstract}
With increasing demands of the job market, occupational stress is becoming a matter of great concern for both employers and employees across the occupations. Individuals try different coping strategies and approaches to keep this stress at a manageable level. This study examined the stress coping strategies and approaches used by the school teachers in respect to their perceived level of stress. A self-developed questionnaire based on COPE inventory was used to conduct this surveybased exploratory study. A sample of 400 school teachers with diverse backgrounds working in both public and private sectors was randomly selected from two district of Punjab. Mean, percentage and t-test were applied to analyze the data. The study found that $60 \%$ of the teachers perceived high or very high level of stress. Female teachers reported more stress than male teachers. 'Turning to religion', 'positive reinterpretation' and 'planning' to actively solve the problem are the mostly used coping strategies. The majority of respondents used problem-oriented and emotion-oriented strategies. Further, it was found that as the level of stress increased, teachers tend towards use of problem and emotion-oriented approaches than avoidance and social-support approaches.
\end{abstract}

Keywords: School teachers, job stress, coping strategies, COPE inventory

\footnotetext{
* Lecturer, Early Childhood Education and Elementary Teacher Education Department, Faculty of Education, Allama Iqbal Open University, Islamabad. Email: nasirhussain99@gmail.com

As Assistant Professor, Department of Education, Bahauddin Zakariya University, Multan

${ }^{* * *}$ Assistant Professor, Institute of Education, Lahore College for Women University, Lahore
} 


\section{Introduction}

Job stress has become almost inescapable in the occupational life of the individuals. There are plenty of studies available to conclude that job stress is prevalent across the occupations (Johnson, Cooper, Cartwright, Donald, \& Taylor, 2005). It negatively affects employees' productivity and health (Ingrid \& Bengt, 2005). As individuals' health, performance and professional development is squeezed due to occupational stress, people all over the world try to keep the stress at a manageable level. Individuals use multiple strategies to cope with their occupational stress. Different aspects of stress have been of great interest for researcher for decades across the globe. Level and determinants of occupational stress, and stress coping strategies have been studied across occupations. Despite extensive research in this field, the interest of the researchers has not waned nor has the importance of the topic.

When we examine teaching as a profession, it consists of two major components i.e. face to face interaction and satisfying the customers once and for all. Both of these components make a profession stressful which makes teaching one of the most vulnerable professions to job stress all over the world (Jepson \& Forrest, 2006). Teachers in Pakistan are also no exception to it and experiencing job stress. Many studies have reported that Pakistani teachers at all levels i.e. from primary to university level are experiencing occupational stress. This study was designed to find out the stress level, and coping strategies and approaches used by the school teachers in respect to their perceived level of occupational stress.

\section{Literature Review}

Working conditions in the educational institutions have become more complex and demanding than before which have resulted in increased level of perceived stress(Barkhuizen, Rothmann, \& van de Vijver, 2014; Wiegel, Sattler, Goritz, \& Diewald, 2015). Though in literature, stress is very often regarded as negative physiological and/or psychological responses yet it has been bifurcated in good stress (eustress) and bad stress (distress). These terms were first documented by Selye (1964) - the pioneer of the 'stress' concept. Though little work has been done to identify determinants of eustress and distress yet it can be construed that a 
stressor, at certain times, may be desirable or undesirable; self-imposed or externally imposed; beneficial or not (Le Fevre, Matheny, \& Kolt, 2003). It might also depend on learning to react the stressor with positive or negative emotions i.e. positive reactions are likely to minimize distress and negative reactions maximize distress (Seyle, 1987). These reactions, also called 'stress coping strategies' are very often directed to control and keep the level of stress at a manageable point.

Coping means the mental and behavioral efforts to handle the situations (Soderstrom, Dolbier, Leiferman, \& Steinhardt, 2000). When we talk about stress coping strategies, it refers to individual's efforts to manage their stress. Coping strategies also refer to cognitive and behavioral approaches used to manage stress (Folkman \& Moskowitz, 2004). Identification of stress coping strategies appealed the interests of many researchers round the globe. Initially, stress coping strategies were categorized into two major styles: problem-focused - dealing with the stressor; and emotion-focused - handling thoughts and feeling associated with the stressor (Folkman \& Lazarus, 1980). When further studies statistically factorized these two coping styles, too much overlapping was noticed which called for alternative models (Carver, Scheier, \& Weintraub, 1989; Deisinger, Cassisi, \&Whitaker, 1996). Carver et al. (1989) added social support and avoidance - avoiding the stressor. Later it was also argued that the coping strategies should be more logically divided into self-support and socially-supported strategies. Both strategies are directed towards managing problems and emotions but still they might look overlapping in some cases. Another bifurcation of coping strategies is made on the basis of solving the stressor or avoiding it. 'Approach-oriented' is positive as it attempts to face and solve the stressor. On the other hand, avoidant coping styles lead towards ignoring and/or withdrawing from the stressor and the attached feelings (Litman, 2006).This bifurcation still misses the clarification that whether approach-oriented approach deals with the solution of the problem or modifying personal feelings attached to the stressor. Furthermore, one of the important aspects of social support is also missing. To sum up, different stress coping models have identified different strategies. 


\section{Job Stress among Pakistani Teachers}

Job stress has turned into a universal dilemma but the sources and levels of stress might be different from country to country (Bhagat, Steverson, \& Segovis, 2007). This difference has attracted the researchers' attention throughout the world towards investigating different dimensions of job stress. The studies regarding job stress of Pakistani teachers show that teachers from university to primary school level reported job related stress ranging from mild to high level (Chuadhry \& Niazi, 2017; Quraishi, Aziz, \& Siddiquah, 2018). These studies have followed different theoretical frameworks. For example, (Usman, Ahmed, Ahmed, \& Akbar, 2011)found that role conflict and role ambiguity are the major reasons of job stress among teachers of the Punjab University, Lahore. The study further concluded that job stress is significantly correlated with job satisfaction and job commitment. On the other hand, in private sector universities of Pakistan, it was found that role conflict, heavy workload and inadequate monetary rewards are the main reasons of teachers' job stress and this stress ultimately leads towards their low efficiency (Ali, Raheem, Nawaz, \& Imamuddin, 2014). Khurshid (2011) developed university teachers' stress inventory which included stress related to work, students, colleagues, administration, and personal factors.

As far as the school teachers are concerned, a high level of job stress was found among Pakistani private school teachers characterized by the perception that their rewards are too less and job demands are too high (Rehman, Khan, \& Afzal, 2010). Another study reveals that private school teachers are facing job stress due to their long working hours, heavy workload, feelings of lack of control at work, and poor relationship and support at the workplace. As a result, decreased presence, productivity and output, and increased medical bills are also evident of high stress (Ali, Ishtiaq, \& Ahmad, 2013).

Similarly, an overwhelming majority of government schools teachers in Punjab (Pakistan) are facing a high level of job stress due to imbalance between perceived efforts and rewards (Hussain, Hameed, Shah, \& Aslam, 2016). They further concluded that government school headteachers are experiencing significantly higher level of job stress than the teachers. Shaheen and Mahmood (2014) found an inverse relationship between teachers' burnout and school resources. The 
majority of secondary school teachers of Federal Government schools feels different level of job stress and this stress is badly affecting their performance (Akhlaq, Amjad, Khalid, Hassan, \& Malik, 2010).

Keeping in view the fact that teachers in Pakistan are experiencing job stress, this study was designed to investigate:

i. What is the perceived level of job stress by the school teachers?

ii. What strategies and approaches are used by the school teaches to cope with their perceived occupational stress?

iii. How do preferred stress coping approaches change with the change in the perceived level of stress?

iv. Is there any difference between male and female teachers regarding perceived level of stress, and coping strategies and approaches?

\section{Theoretical Framework}

COPE inventory was developed by Carver et al. in 1989 but still widely used by the researchers across the globe. Four factors and 15 subscales were identified by Craver et al. COPE inventory was subsequently factorized in many studies. Litman (2006) has reported nine such studies along with the original factorization by Carver and his colleagues (1989). These studies covered a period of 15 years (1989 to 2003). Many subscales loaded on the same factor throughout the studies. This study included only those sub-scales which loaded on the same factor in more than half of the studies. The only exception was 'Turning to religion' as it loaded on emotion-focused factor in two studies while three of the studies mentioned it as a separate factor. Four of the studies didn't provide information about it and one study did not include it. The social settings in which this study was conducted are thought to be highly inclined towards religion. Despite including it as a separate factor, it was integrated in emotion-focused factor to keep the number of factors equivalent to majority of the studies. In this way, 12 sub-scales were included in the study. Three sub-scales i.e. Substance use, Acceptance and Humor were eliminated. 
Table 1

Dimensionality of COPE Scales in Ten Studies (adopted from

Litman, 2006)

\begin{tabular}{|c|c|c|c|c|c|c|c|c|c|c|}
\hline $\begin{array}{l}\text { Stress coping } \\
\text { sub-scales }\end{array}$ & 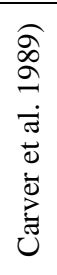 & 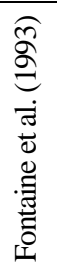 & 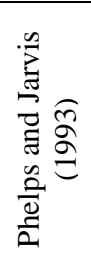 & 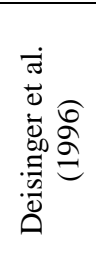 & 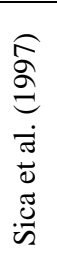 & 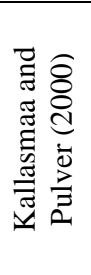 & 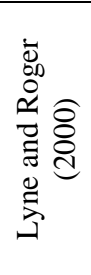 & 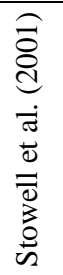 & 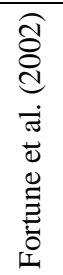 & 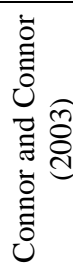 \\
\hline Active* & $\mathrm{a}$ & a & $\mathrm{a}$ & $\underline{b} / a^{3}$ & $\mathrm{a}$ & $\mathrm{a}$ & $\mathrm{a}$ & $\mathrm{a}$ & $\mathrm{a}$ & $\mathrm{a}$ \\
\hline Planning* & $\mathrm{a}$ & $\mathrm{a}$ & $\mathrm{a}$ & $\mathrm{a}$ & $\mathrm{a}$ & $\mathrm{a}$ & $\mathrm{a}$ & a & $\mathrm{a}$ & $\mathrm{a}$ \\
\hline Suppression* & $\mathrm{a}$ & $\mathrm{a}$ & $\mathrm{a}$ & $\mathrm{a}$ & $\mathrm{a}$ & $\mathrm{a}$ & $\mathrm{a}$ & $\mathrm{a}$ & $\mathrm{a}$ & $\mathrm{a}$ \\
\hline $\begin{array}{l}\text { Behavioral } \\
\text { disengagement* }\end{array}$ & $\mathrm{b}$ & b & $\mathrm{b}$ & $\mathrm{b}$ & $\mathrm{b}$ & $\mathrm{b}$ & $\underline{\mathrm{C}}$ & $\mathrm{b}$ & $\mathrm{b}$ & $\mathrm{b}$ \\
\hline Denial* & $\mathrm{b}$ & b & b & $\mathrm{b}$ & $\mathrm{b}$ & $\mathrm{b}$ & $\mathrm{b}$ & $\mathrm{b}$ & $\mathrm{b}$ & $\mathrm{b}$ \\
\hline $\begin{array}{l}\text { Mental } \\
\text { disengagement* }\end{array}$ & $\mathrm{b}$ & b & $\mathrm{d}$ & $\mathrm{b}$ & $\mathrm{b}$ & $\mathrm{b}$ & $\mathrm{b}$ & $\mathrm{b}$ & $\mathrm{b}$ & $\mathrm{X}$ \\
\hline Substance use ${ }^{* *}$ & $\mathrm{X}$ & b & $b$ & e & $\mathrm{b}$ & 0 & $\mathrm{X}$ & $X$ & $\mathrm{X}$ & $\mathrm{b}$ \\
\hline $\begin{array}{l}\text { Emotional social } \\
\text { support* }^{*}\end{array}$ & $\mathrm{C}$ & C & C & $\mathrm{C}$ & $\mathrm{C}$ & C & $\underline{b} / \mathrm{c}^{4}$ & C & $\mathrm{C}$ & $\mathrm{C}$ \\
\hline $\begin{array}{l}\text { Instrumental } \\
\text { social support* }\end{array}$ & C & C & $\mathrm{a}$ & $\mathrm{C}$ & C & C & $\mathrm{C}$ & C & $\mathrm{C}$ & $\mathrm{C}$ \\
\hline $\begin{array}{l}\text { Venting } \\
\text { emotions* }\end{array}$ & C & C & C & $\mathrm{C}$ & C & C & 0 & C & C & $\mathrm{C}$ \\
\hline $\begin{array}{l}\text { Positive } \\
\text { reinterpretation* }\end{array}$ & d & $\mathrm{d}$ & $\mathrm{d}$ & $\mathrm{d}$ & $\mathrm{d}$ & $\mathrm{a}$ & $\mathrm{a}$ & a & $\mathrm{a}$ & $\mathrm{d}$ \\
\hline Restraint * & $\mathrm{d}$ & d & $\mathrm{d}$ & $\mathrm{d}$ & $\mathrm{d}$ & $\underline{\mathrm{b}}$ & $\mathrm{a}$ & $\mathrm{a}$ & $\mathrm{a}$ & $\mathrm{d}$ \\
\hline Acceptance** & $\mathrm{d}$ & $\mathrm{d}$ & $\mathrm{d}$ & $\mathrm{a}$ & $\mathrm{d}$ & $\underline{\mathrm{b}}$ & $\mathrm{a}$ & $\mathrm{a}$ & $\mathrm{a}$ & $\mathrm{a}$ \\
\hline $\begin{array}{l}\text { Turning to } \\
\text { religion* }\end{array}$ & $\mathrm{d}$ & 0 & 0 & $\mathrm{~d}$ & $\mathrm{f}$ & $X$ & $\mathrm{f}$ & 0 & $\mathrm{f}$ & 0 \\
\hline Humor** & $X$ & b & 0 & $\underline{\mathrm{e}}$ & $\mathrm{b}$ & $\underline{\mathrm{a}}$ & $X$ & $X$ & $\underline{f}$ & 0 \\
\hline \multicolumn{11}{|c|}{$\begin{array}{l}\mathrm{a}=\text { Problem-focused; } \mathrm{b}=\text { Avoidant coping; } \mathrm{c}=\text { Social-support; } \mathrm{d}=\text { Emotion- } \\
\text { focused; } \mathrm{e}=\text { Substance use and humor; } \mathrm{f}=\text { Religion; } \mathrm{X}=\text { Not included; } 0=\text { No } \\
\text { information given }\end{array}$} \\
\hline
\end{tabular}




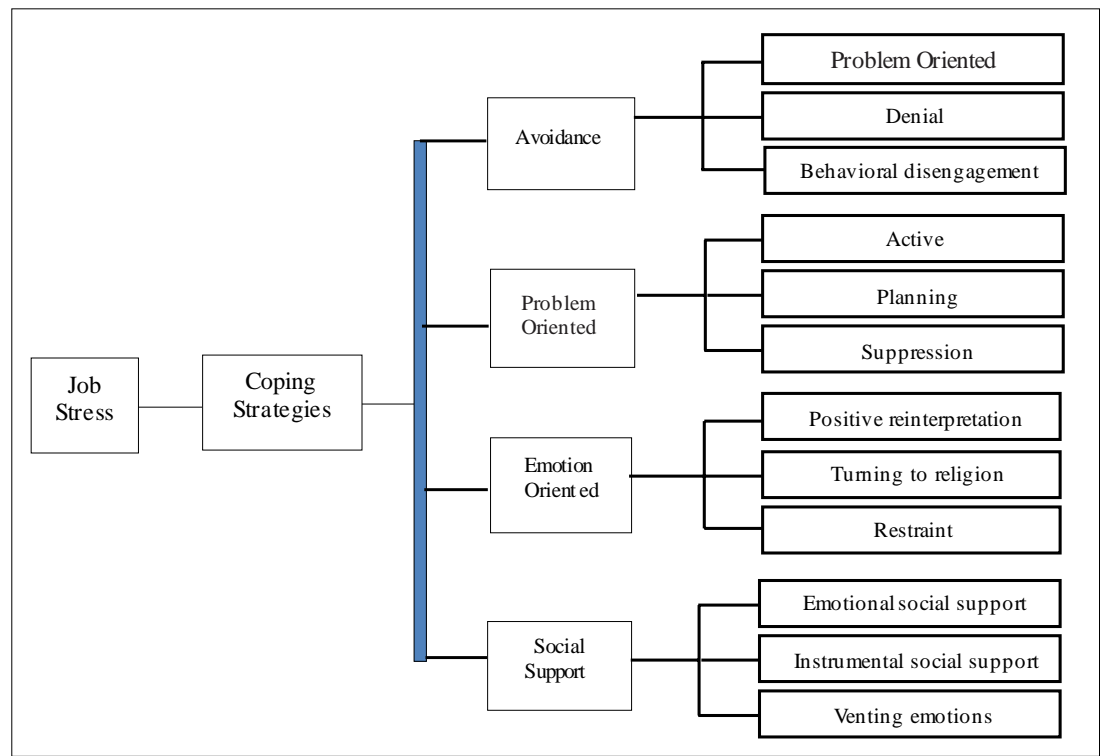

Figure 1: Framework of the Study

\section{Methodology}

Mostly, the stress related studies have used quantitative research design. An exploratory quantitative research design was adopted to collect the data from a sample of 400 teachers working in public or private sector. The study sampling framework supported the diverse backgrounds and demographics of the respondents to get the comprehensive information. Two districts (Lahore and Mianwali) were involved to collect the data. Initially, the schools were selected purposively so that our sample might represent a vast range of the teachers and the teachers over there were randomly selected and asked to fill the questionnaire. The sample consisted of 199 male and 201 female teachers; 223 urban and 177 rural school teachers; 227 government, 168 private and five semi-government school teachers; 178 teachers were holding a permanent position while 95 were temporary and 127 were working on contract basis.

A questionnaire was developed to collect the data which mainly targeted two aspects i.e. level of stress and coping strategies/approaches used by the respondents. The framework of the study drew four approaches. Every approach comprises three strategies. Key words of the COPE Inventory were used to develop the statements. The questionnaire were validated by two language experts. It was also pilot tested on 40 teachers. The reliability of the research instrument was 0.784 (Cronbach 
Alpha). Five statements were designed to measure the level of teachers' stress based on five point scale from 'Almost Always' to 'Almost Never'. While the 12 statements measuring the stress coping strategies and approaches were based on five point rating scale ranging from 'Almost Always' to 'Almost Never'. The participants were asked to respond against each statement that how much they use a particular strategy to cope with their job stress. The score on each statement representing a particular strategy. These scores were added to identify a particular approach. The approach with the highest score was considered as the most preferred approach of the respondent. In some cases where the respondents' scores were equal on more than one approach, both were counted as their preferred approaches. In some cases, individuals reported use of two or more approaches and all reported approaches were included in the analysis, the percentages of preferred approaches might exceed from 100, if added (Table 5). As the available literature strongly supports the use of gender as a stress moderator, t-test was applied to find out significant differences in the perceptions of male and female respondents.

\section{Findings}

Table 2

Frequency Distribution of Perceived Level of Job Stress

\begin{tabular}{lcc}
\hline \multicolumn{1}{c}{ Level of Stress } & Frequency & Percent \\
\hline No Stress & 3 & 0.8 \\
Low Stress & 26 & 6.5 \\
Moderate Stress & 131 & 32.8 \\
High Stress & 193 & 48.3 \\
Very High Stress & 47 & 11.8 \\
Total & 400 & 100.0 \\
\hline
\end{tabular}

Table 2 shows that three respondents $(0.8 \%)$ were facing no stress at all. Around $40 \%$ of our respondents reported low $(6.5 \%)$ or moderate $(32.8 \%)$ level of stress. Whereas, almost half of the respondents (48.3\%) reported high level of stress and $11.8 \%$ were experiencing very high level of stress.

Table 3

t test Based on Gender Regarding Perceived Level of Stress

\begin{tabular}{lccccc}
\hline Gender & $\mathrm{N}$ & Mean & SE & $t$ & Sig. \\
\hline Male & 199 & 17.55 & .25930 & \multirow{2}{*}{-3.023} & $.003^{* *}$ \\
Female & 201 & 18.66 & .25951 & &
\end{tabular}


Table 3 shows that female teachers perceived more stress $(M=$ 18.66) than the male teachers $(M=17.55)$ and this difference is statistically significant $(t=-3.023)$ at $p<0.01$.

Table 4

Perceptions regarding Stress Coping Strategies and Approaches

\begin{tabular}{|c|c|c|c|c|c|c|c|c|c|}
\hline Approach & Strategy & Never & Rarely & Usually & Often & Always & Mean & $\mathrm{SD}$ & $\begin{array}{l}\text { Factor } \\
\text { mean }\end{array}$ \\
\hline \multirow{3}{*}{$\begin{array}{l}\text { Avoidance } \\
\text { oriented }\end{array}$} & $\begin{array}{l}\text { Mental } \\
\text { disengagement }\end{array}$ & $\begin{array}{c}55 \\
13.8 \%\end{array}$ & $\begin{array}{c}84 \\
21.0 \%\end{array}$ & $\begin{array}{c}54 \\
13.5 \%\end{array}$ & $\begin{array}{c}136 \\
34.0 \%\end{array}$ & $\begin{array}{c}71 \\
17.8 \%\end{array}$ & 3.21 & 1.33 & \multirow{3}{*}{2.73} \\
\hline & Denial & $\begin{array}{c}63 \\
15.8 \%\end{array}$ & $\begin{array}{c}71 \\
17.8 \%\end{array}$ & $\begin{array}{c}114 \\
28.5 \%\end{array}$ & $\begin{array}{c}108 \\
27.0 \%\end{array}$ & $\begin{array}{c}44 \\
11.0 \%\end{array}$ & 3.00 & 1.23 & \\
\hline & $\begin{array}{l}\text { Behavioral } \\
\text { disengagement }\end{array}$ & $\begin{array}{c}202 \\
50.5 \%\end{array}$ & $\begin{array}{c}91 \\
22.8 \%\end{array}$ & $\begin{array}{c}41 \\
10.3 \%\end{array}$ & $\begin{array}{c}48 \\
12.0 \%\end{array}$ & $\begin{array}{c}18 \\
4.5 \%\end{array}$ & 1.97 & 1.22 & \\
\hline \multirow{3}{*}{$\begin{array}{l}\text { Problem } \\
\text { oriented }\end{array}$} & Active & $\begin{array}{c}15 \\
3.8 \%\end{array}$ & $\begin{array}{c}21 \\
5.3 \%\end{array}$ & $\begin{array}{c}63 \\
15.8 \%\end{array}$ & $\begin{array}{c}88 \\
22.0 \%\end{array}$ & $\begin{array}{c}213 \\
53.3 \%\end{array}$ & 4.16 & 1.10 & \multirow{3}{*}{4.08} \\
\hline & Planning & $\begin{array}{c}16 \\
4.0 \%\end{array}$ & $\begin{array}{c}19 \\
4.8 \%\end{array}$ & $\begin{array}{c}44 \\
11.0 \%\end{array}$ & $\begin{array}{c}84 \\
21.0 \%\end{array}$ & $\begin{array}{c}237 \\
59.3 \%\end{array}$ & 4.27 & 1.09 & \\
\hline & Suppression & $\begin{array}{c}20 \\
5.0 \%\end{array}$ & $\begin{array}{c}36 \\
9.0 \%\end{array}$ & $\begin{array}{c}102 \\
25.5 \%\end{array}$ & $\begin{array}{c}81 \\
20.3 \%\end{array}$ & $\begin{array}{c}161 \\
40.3 \%\end{array}$ & 3.82 & 1.20 & \\
\hline \multirow{3}{*}{$\begin{array}{l}\text { Emotion } \\
\text { oriented }\end{array}$} & $\begin{array}{l}\text { Positive } \\
\text { reinterpretation }\end{array}$ & $\begin{array}{c}12 \\
3.0 \%\end{array}$ & $\begin{array}{c}21 \\
5.3 \%\end{array}$ & $\begin{array}{c}46 \\
11.5 \%\end{array}$ & $\begin{array}{c}83 \\
20.8 \%\end{array}$ & $\begin{array}{c}238 \\
59.5 \%\end{array}$ & 4.29 & 1.05 & \multirow{3}{*}{4.05} \\
\hline & $\begin{array}{l}\text { Turning to } \\
\text { religion }\end{array}$ & $\begin{array}{c}14 \\
3.5 \%\end{array}$ & $\begin{array}{c}17 \\
4.3 \%\end{array}$ & $\begin{array}{c}48 \\
12.0 \%\end{array}$ & $\begin{array}{c}37 \\
9.3 \%\end{array}$ & $\begin{array}{c}284 \\
71.0 \%\end{array}$ & 4.40 & 1.08 & \\
\hline & Restraint & $\begin{array}{c}31 \\
7.8 \%\end{array}$ & $\begin{array}{c}57 \\
14.3 \%\end{array}$ & $\begin{array}{c}107 \\
26.8 \%\end{array}$ & $\begin{array}{c}109 \\
27.3 \%\end{array}$ & $\begin{array}{c}96 \\
24.0 \%\end{array}$ & 3.46 & 1.22 & \\
\hline \multirow{3}{*}{$\begin{array}{l}\text { Social } \\
\text { Support }\end{array}$} & $\begin{array}{l}\text { Emotional } \\
\text { social support }\end{array}$ & $\begin{array}{c}64 \\
16.0 \%\end{array}$ & $\begin{array}{c}75 \\
18.8 \%\end{array}$ & $\begin{array}{c}63 \\
15.8 \%\end{array}$ & $\begin{array}{c}71 \\
17.8 \%\end{array}$ & $\begin{array}{c}127 \\
31.8 \%\end{array}$ & 3.31 & 1.48 & \multirow{3}{*}{3.70} \\
\hline & $\begin{array}{l}\text { Instrumental } \\
\text { social support }\end{array}$ & $\begin{array}{c}21 \\
5.3 \%\end{array}$ & $\begin{array}{c}37 \\
9.3 \%\end{array}$ & $\begin{array}{c}54 \\
13.5 \%\end{array}$ & $\begin{array}{c}118 \\
29.5 \%\end{array}$ & $\begin{array}{c}170 \\
42.5 \%\end{array}$ & 3.95 & 1.18 & \\
\hline & $\begin{array}{l}\text { Venting } \\
\text { emotions }\end{array}$ & $\begin{array}{c}25 \\
6.3 \%\end{array}$ & $\begin{array}{c}41 \\
10.3 \%\end{array}$ & $\begin{array}{c}65 \\
16.3 \%\end{array}$ & $\begin{array}{c}106 \\
26.5 \%\end{array}$ & $\begin{array}{c}163 \\
40.8 \%\end{array}$ & 3.85 & 1.23 & \\
\hline
\end{tabular}

Table 4 shows what strategies are used by the respondents to cope with job stress. The respondents reported that they usually want to spend time alone $(M=3.21, S D=1.33)$ or deny that it's a real problem ( $M=3.00, S D=1.23)$ but rarely disengage themselves from the school 
activities $(M=1.97, S D=1.22)$. Whereas, they expressed that more than often they take steps to eliminate the problem $(M=4.16, S D=1.10)$ or continuously think how to deal with the problem $(M=4.27, S D=1.09)$. The majority of them also expressed that they remain focused on the problem $(M=3.82, S D=1.20)$. While explaining their emotions, an overwhelming majority of the respondents reported that they try to rectify their mistakes to further avoid such situation in future $(M=4.29$, $S D=1.05)$ or turn to religion for mental peace $(M=4.40, S D=1.08)$. The majority of them also reported that they restrain themselves and wait for a suitable time to react $(M=3.46, S D=1.22)$. The majority of the respondents also reported that they openly discuss the problem $(M=$ $3.85, S D=1.23)$ to get sympathy from family and friends $(M=3.31, S D$ $=1.48)$ or seek advice from superiors/friends to solve the problem $(M=$ 3.95, $S D=1.18$ ).

Factor means were calculated to find an overall trend of the approaches used to cope with the job stress among the respondents which tell that problem-oriented (Factor mean $=4.08$ ) and emotion-oriented (Factor mean $=4.05$ ) are widely used approaches used by the respondents followed by social support approach $($ Factor mean $=3.70)$ while the least preferred approach was found to be avoidance approach $($ Factor mean $=2.73)$.

Table 5

Stress Coping Approaches in Relation with Perceived Levels of Stress

\begin{tabular}{lcccc}
\hline \multicolumn{1}{c}{ Level of Stress } & Avoidance & Problem & Emotion & Social Support \\
\hline Low Stress (26) & 5 & 11 & 9 & 8 \\
& $(19.2 \%)$ & $(42.3 \%)$ & $(34.6 \%)$ & $(30.8 \%)$ \\
Moderate Stress (131) & 20 & 59 & 58 & 40 \\
& $(15.3 \%)$ & $(45.0 \%)$ & $(44.3 \%)$ & $(30.5 \%)$ \\
High Stress (193) & 21 & 100 & 99 & 51 \\
& $(10.9 \%)$ & $(51.8 \%)$ & $(51.3 \%)$ & $(26.4 \%)$ \\
Very High Stress (47) & - & 35 & 19 & 20 \\
& & $(74.5 \%)$ & $(40.4 \%)$ & $(42.6 \%)$ \\
\hline
\end{tabular}

Table 5 explains the stress coping approaches in relation to the level of stress of the respondents. Problem-oriented approach is mostly used by the respondents. More people tend to problem-oriented approach as the level of stress increases from low stress (42.3\%) to moderate level of stress and from high stress level (51.8\%) to very high level of stress (74.5\%). The use of emotion-oriented approach also increases from low stress (34.6\%) to moderate stress (44.3\%) and high stress (51.3\%) but a number of respondents to use emotion-oriented approach decreases when 
they face very high level of job stress (40.4\%). Almost same percentage of participants reported that they seek social support when they face low stress (30.8\%) or moderate stress (30.5\%). But this percentage decreases when they perceive high stress (26.4\%), and as they start feeling very high level of stress, they start seeking social support more (42.6\%). As far as the avoidance approach is concerned, as the level of stress intensifies, the percentage of participants who use this approach becomes lesser and lesser i.e. 19.2\% use this approach when they feel low stress, $15.3 \%$ when the stress level is moderate, and $10.9 \%$ when they experience high stress. While none of our respondents reported that they avoid the problem which is causing very high level of job stress.

Table 6

t test Based On Gender for Stress Coping Strategies

\begin{tabular}{|c|c|c|c|c|c|c|}
\hline Strategies & Gender & $\mathrm{N}$ & Mean & $S E$ & $t$ & Sig. \\
\hline \multirow{2}{*}{$\begin{array}{l}\text { Mental } \\
\text { disengagement }\end{array}$} & Male & 199 & 3.07 & .094 & \multirow{2}{*}{$-2.098^{*}$} & \multirow{2}{*}{.037} \\
\hline & Female & 201 & 3.35 & .093 & & \\
\hline \multirow{2}{*}{ Denial } & Male & 199 & 3.02 & .093 & \multirow{2}{*}{0.364} & \multirow{2}{*}{.716} \\
\hline & Female & 201 & 2.98 & .081 & & \\
\hline \multirow{2}{*}{$\begin{array}{l}\text { Behavioral } \\
\text { disengagement }\end{array}$} & Male & 199 & 2.01 & .091 & \multirow{2}{*}{0.611} & \multirow{2}{*}{.542} \\
\hline & Female & 201 & 1.94 & .082 & & \\
\hline \multirow{2}{*}{ Active } & Male & 199 & 4.11 & .083 & \multirow{2}{*}{-0.938} & \multirow{2}{*}{.349} \\
\hline & Female & 201 & 4.21 & .072 & & \\
\hline \multirow{2}{*}{ Planning } & Male & 199 & 4.10 & .083 & \multirow{2}{*}{$-3.087^{* *}$} & \multirow{2}{*}{.002} \\
\hline & Female & 201 & 4.43 & .069 & & \\
\hline \multirow{2}{*}{ Suppression } & Male & 199 & 3.86 & .086 & \multirow{2}{*}{0.777} & \multirow{2}{*}{.438} \\
\hline & Female & 201 & 3.77 & .083 & & \\
\hline \multirow{2}{*}{$\begin{array}{l}\text { Positive } \\
\text { reinterpretation }\end{array}$} & Male & 199 & 4.27 & .078 & \multirow{2}{*}{-0.352} & \multirow{2}{*}{.725} \\
\hline & १Female & 201 & 4.30 & .071 & & \\
\hline \multirow{2}{*}{$\begin{array}{l}\text { Turning to } \\
\text { religion }\end{array}$} & Male & 199 & 4.23 & .085 & \multirow{2}{*}{$-3.254^{* *}$} & \multirow{2}{*}{.001} \\
\hline & Female & 201 & 4.57 & .064 & & \\
\hline \multirow{2}{*}{ Restraint } & Male & 199 & 3.29 & .090 & \multirow{2}{*}{$-2.695^{* *}$} & \multirow{2}{*}{.007} \\
\hline & Female & 201 & 3.62 & .080 & & \\
\hline $\begin{array}{l}\text { Emotional } \\
\text { social support }\end{array}$ & Male & 199 & 3.46 & .102 & $2.126^{*}$ & \multirow{2}{*}{.034} \\
\hline \multirow{2}{*}{$\begin{array}{l}\text { Instrumental } \\
\text { social support }\end{array}$} & Made & 201 & $\begin{array}{l}3.15 \\
3.98\end{array}$ & .106 & \multirow{2}{*}{0.544} & \\
\hline & Female & 201 & 3.92 & .081 & & .587 \\
\hline \multirow{2}{*}{$\begin{array}{l}\text { Venting } \\
\text { emotions }\end{array}$} & Male & 199 & 3.86 & .088 & 0190 & 849 \\
\hline & Female & 201 & 3.84 & .087 & 0.190 & . \\
\hline
\end{tabular}


Table 6 shows significant differences between the coping strategies used by male and female respondents. On average, female participants tend to spend time alone $(M=3.35, S E=.093)$ than male participants ( $M$ $=3.07, S E=.094)$, and this difference is significant at $p<0.05$. In the same way, female participants $(M=4.43, S E=.069)$ reported more than the male participants $(M=4.10, S E=.083)$ that they continuously think about the problem, and this difference is statistically significant at $p<$ 0.01 . Overall, female respondents turn to religion to counter stress $(M=$ 4.57, $S E=.064)$ more than the male respondents do $(M=4.23, S E=$ .085 ) and this difference is significant at $p<0.01$. The female respondents $(M=3.62, S E=.080)$, on average, reported significantly more $(p<0.01)$ than their male counterparts $(M=3.29, S E=.090)$ that they restrain themselves and wait for a suitable time to react on the stress causing problem. On the contrary, male respondents $(M=3.46, S E=$ .102) like more to share the problem with their friends/family to get sympathy than the female respondents $(M=3.15, S E=.106)$ and this difference is significant at $p<0.05$. As far as the stress coping strategies like denial the problem $(t=0.346)$, keeping away from school activities $(t=0.611)$, actively trying to eliminate the problem $(t=-0.938)$, remaining focused on problem only $(t=0.777)$, rectifying themselves to avoid such problems in future $(t=-0.352)$, seeking advice from superiors/friends ( $t=0.544$ ) openly discussing the problem $(t=0.190)$ were concerned, the difference in male and female participants were statistically not significant.

Table 7

t test Based on Gender for Stress Coping Approaches

\begin{tabular}{llccccc}
\hline Approaches & Gender & $\mathrm{N}$ & Mean & $S E$ & $t$ & Sig. \\
\hline \multirow{2}{*}{ Avoidance } & Male & 199 & 8.10 & .176 & \multirow{2}{*}{0.669} & \multirow{2}{*}{0.504} \\
& Female & 201 & 8.26 & .158 & & \\
Problem & Male & 199 & 12.07 & .208 & -1.263 & \multirow{2}{*}{0.207} \\
& Female & 201 & 12.41 & .174 & & \\
Emotion & Male & 199 & 11.78 & .190 & $-2.749^{* *}$ & \multirow{2}{*}{0.006} \\
Social & Female & 201 & 12.49 & .174 & & \\
Support & Male & 199 & 11.31 & .224 & \multirow{2}{*}{1.317} & 0.189 \\
\hline${ }_{*}^{* *}$ Female & 201 & 10.91 & .206 & & \\
\hline
\end{tabular}

${ }^{* *} p<0.01$ 
Table 7 depicts differences in stress coping approaches adopted by male and female respondents. Female respondents $(M=8.26, S E=.158)$ use avoidance-oriented approach more than the male respondents $(M=$ $8.10, S E=.176)$ but this difference is insignificant $(t=-0.669)$ at $p<$ 0.05 . Female respondents $(M=12.41, S E=.158)$ also prefer problemoriented approach than the male participants $(M=12.07, S E=.208)$.But this difference is also not significant $(t=-1.263)$ at $p<0.05$. Male respondents $(M=11.31, S E=.224)$ seek more social support than the female respondents $(M=10.91, S E=.206)$ but this difference is also insignificant $(t=1.317)$ at $p<0.05$. The only significant difference $(t=-$ 2.749) at $p<0.01$ was found in emotion-oriented approach where female respondents $(M=12.49, S E=.174)$ reported more use of this approach than male respondents $(M=11.78, S E=.190)$.

\section{Discussion}

This study was conducted to investigate the stress level of the school teachers and their stress coping strategies and approaches. The study found that the majority of teachers are experiencing high or very high level of stress. The 'human service' professions - including teaching which require exhibiting emotions during face to face or voice to voice interactions with the clients are likely to be more vulnerable to job stress(Johnson et al., 2005).Earlier studies also found that school teachers in Pakistan like any other part of the world, have reported high level of job stress (Hussain, Hameed, Shah, \& Aslam, 2016; Pervez \& Hanif, 2003). Our study identified that female respondents perceive more job stress than their male counterparts. Our findings are in line with the study results of Bano and Malik (2014) who concluded that female teachers perceive significantly more stress than male teachers.

As to identifying stress coping strategies, the present study found that 'turning to religion' and 'positive reinterpretation' are the mostly adopted coping strategies by the teachers. In an orthodox society, where people strongly believe that religion is the ultimate reality, turning to religion in despair and stress as the supreme/topmost coping strategy is not surprising. Turning to religion found a common coping strategy even in western countries. The study of Gebrekirstos (2015) reached to same conclusion that most of the teachers in secondary schools turned to 
religion at the time of depression and anxiety in their professional lives. As far as other coping strategies were concerned, the study found that the majority of teachers use problem-oriented and/or emotion-oriented approaches to cope with their job stress. This is also in line with the study findings of Chitsiko, Mapfumo and Chireshe (2012), they conducted their study in African context to examine the stressor and coping strategies of teachers and students.

Next, social support also found to be significant coping strategy by the teachers. A number of teachers prefer seeking social support when their stress increases. These findings corroborate with the earlier research conducted in a developing country context, identified that school teachers start seeking support from each other in the school when are under stress (Murray-Harvey \& Slee, 2007; Wasburn-Ormachea, Hillman, \& Sawilowsky, 2004). They use to seek social support in a number of ways e.g., taking help from senior colleagues, friends, and sometimes from outside school community (Gebrekirstos, 2015).

Another important factor in our research was comparison of male and female teachers stress level and coping strategies: female teachers more inclined to live alone, turn to religion, and restrain their emotions than their male counterparts. They became more introvert and preferred to be quite. These findings are validated by the study results of KortButler (2008), who concluded that females reported higher stress levels in relationships with parents, peers, and colleagues than males. Moreover, male and female teachers also differ with respect to adopt certain coping strategies. Chitsiko, Mapfumo and Chireshe (2012) also identified a number of differences e.g. female teachers remain quite, they restrain their emotions, turn to religion, absent from the duty etc. between male and female teachers in view of coping with occupational stress.

\section{Conclusions}

This study was designed to assess the level of job stress among school teachers and investigate the strategies and approaches to cope with this stress. The study found that the majority of school teachers are experiencing high level of job stress. To cope with the job stress, teachers mostly turn to their religions. Further, they also try to rectify themselves so that such problem might not emerge again in future. They 
also continuously think about dealing with the problem. During job stress, female teachers want more to live alone, plan to remove the problem, turn to religion, restrain their emotions and wait for a suitable time to react than their male counterparts. While male teachers try to get sympathy of their family/friends more than the female teachers do.

As far as the stress coping approaches are concerned, mostly school teachers use problem-oriented and emotion-oriented approaches. When they face job stress, they try to actively solve the problem and also focus to improve their emotions. As the level of stress intensifies, more and more people tend to adopt problem-oriented, emotion-oriented and social support approaches but when people face very high level of stress, they become less emotion-oriented. On the contrary, school teachers avoid the stressors when the stress level is low. As the stress level increases, lesser people avoid the problem and when the stress increases to very high level, no one tries to avoid the problem rather they actively focus and try to solve the problem. 


\section{References}

Akhlaq, M., Amjad, B., Khalid, M. M., Hassan, S., \& Malik, S. (2010). An evaluation of the effects of stress on the job performance of secondary school teachers. Journal of Law and Psycholoy, 1(1), 43-54.

Ali, K., Ishtiaq, I., \& Ahmad, M. (2013). Occupational stress effects and job performance in the teachers of schools of Punjab (Pakistan). International Journal of Academic Research in Business and Social Sciences, 3(11), 665-680.

Ali, W. U., Raheem, A. R., Nawaz, A., \& Imamuddin, K. (2014). Impact of stress on job performance: An empirical study of employees of private sector universities of Karachi, Pakistan. Research Journal of Management Sciences, 3(7), 14-17.

Bano, S., \& Malik, S. D. (2014). Effect of Occupational Stress on Life Satisfaction among Private and Public School Teachers. Journal of Independent Studies and Research-Management, Social Sciences and Economics, 12(1), 17-27.

Barkhuizen, N., Rothmann, S., \& van de Vijver, F. J. (2014). Burnout and Work Engagement of Academics in Higher Education Institutions: Effects of Dispositional Optimism. Stress and Health, 30(4), 322-332.

Bhagat, R. S., Steverson, P. K., \& Segovis, J. C. (2007). International and cultural variations in employee assistance programmes: Implications for managerial health and effectiveness. Journal of Management Studies, 44(2), 222-242.

Carver, C. S., Scheier, M. F., \& Weintraub, J. K. (1989). Assessing Coping Strategies; A Theoretically Based Approach. Journal of Personality and Social Psychology, 56(2), 267-283.

Chitsiko, N., Mapfumo, J. S., \& Chireshe, R. (2012). Teaching practice generated stressors and coping mechanisms among student teachers in Zimbabwe. South African Journal of Education, 32(2), 155-166.

Chuadhry, M. A., \& Niazi, H. K. (2017). Job Stress of academia and its effect on their performance in public sector universities of Punjab. Pakistan Journal of Education, 34(2), 101-118.

Deisinger, J. A., Cassisi, J. E., \& Whitaker, S. L. (1996). Relationships between coping style and PAI Profiles in a community sample. Journal of Clinical Psychology, 52(3), 303-310. 
Folkman, S., \& Lazarus, R. S. (1980). An analysis of coping in a middleaged community sample. Journal of Health and Social Behavior, 21(3), 219-239.

Folkman, S., \& Moskowitz, J. T. (2004). Coping: Pitfalls and promise. Annual Review of Psychology, 55, 740-745.

Gebrekirstos, H. A. (2015). Occupational stress among secondary school teachers and their coping strategies: The case of Central Zone of Tigray Region. International Journal of Academic Research Educational Review, 3(6), 143-157.

Hussain, S. N., Hameed, A., Shah, Z. A., \& Aslam, M. M. (2016). Understanding relationship between effort-reward imbalance and job stress: An evidence from Pakistani Schools. PONTE, 72(4), 177-191.

Ingrid, A., \& Bengt, A. (2005). The impact of a prospective survey-based workplace intervention program on employee health, biologic stress makers, and organizational productivity. Journal of Occupational and Environmental Medicine, 47(7), 671-682.

Jepson, E., \& Forrest, S. (2006). Individual contributory factors in teacher stress: The role of achievement striving and occupational commitment. British Journal of Educational Psychology, 76, 183-197.

Johnson, S., Cooper, C., Cartwright, S., Donald, I., \& Taylor, P. (2005). The experience of work-related stress across occupations. Journal of Managerial Psychology, 20(2), 178-187.

Khurshid, F. (2011). Development of university teachers' stress inventory. Pakistan Journal of Education, 28(1), 19-30.

Kort-Butler, L. A. (2008). Coping styles and sex differences in depressive symptoms and delinquent behavior. Journal of Youth and Adolescence, 38, 122-136.

Le Fevre, M., Matheny, J., \& Kolt, G. S. (2003). Eutress, distres, and interpretation in occupational stress. Journal of Managerial Psychology, 28(7), 726-744.

Litman, J. A. (2006). The COPE Inventory: Dimensionality and relationships with approach- and avoidance-motives and positive and negative traits. Personality and Individual Differences, 41, 273-284.

Murray-Harvey, R., \& Slee, P. T. (2007). Supportive and stressful relationships with teachers, peers and family and their influence on 
students' social/emotional and academic experience of school. Australian Journal of Guidance and Counseling, 17, 126 -147.

Pervez, S., \& Hanif, R. (2003). Levels and sources of work stress among women school teachers.Pakistan Journal of Psychological Research, 18(3-4), 97-108.

Quraishi, U., Aziz, F., \& Siddiquah, A. (2018). Stress and coping strategies of university teachers in Pakistan. Pakistan Journal of Education, 35(2), 193-206.

Rehman, S., Khan, M. A., \& Afzal, H. (2010). An investigative relationship between Effort-Reward Model and job stress in private educatitonal institutions: A validation study. International Journal of Business and Management, 5(3), 42-51.

Selye, H. (1964). From Dream to Reality. New York: McGraw-Hill.

Seyle, H. (1987). Stress without Distress. London: Transworld.

Shaheen, F., \& Mahmood, N. (2014). Schools as antecedents of teacher burnout: A case of public sector schools in Lahore. Pakistan Journal of Education, 34(1), 79-94.

Soderstrom, M., Dolbier, C., Leiferman, J., \& Steinhardt, M. (2000). The relationship of hardiness, coping strategies, and perceived stress to symptoms of illness. Journal of Behavioral Medicine, 23(3), 311-328.

Usman, A., Ahmed, D. Z., Ahmed, I., \& Akbar, Z. (2011). Work stress experienced by the teaching staff of Univeristy of Punjab, Pakistan: Antecedents and consequences. International Journal of Business and Social Sciences, 2(8), 202-210.

Wasburn-Ormachea, J. M., Hillman, S. B., \& Sawilowsky, S. S. (2004). Gender and gender-role orientation differences in adolescents' coping with peer stressors. Journal of Youth and Adolescence, 33, 31-40.

Wiegel, C., Sattler, S., Goritz, A. S., \& Diewald, M. (2015). Workrelated Stress and Cognitive Enhancement Among University Teachers. Anxiety, Stress, \& Coping, 26(1), 100-117.

\section{Citation of this Article:}

Hussain, S. N., Zulfqar, A., \& Aziz, F. (2019). Analyzing stress coping strategies and approaches of school teachers. Pakistan Journal of Education, 36(1), 01-18. 